\title{
Odporność na zimne pękanie złączy spawanych ze stali P460NL1
}

\section{Resistance to cold cracking of welded joints of P460NL1 steel}

\section{Streszczenie}

Przedstawiono wyniki badań odporności na zimne pękanie złączy spawanych ze stali o podwyższonej wytrzymałości przeznaczonej do pracy pod ciśnieniem P460NL1. Spawanie prowadzono elektrodami otulonymi (MMA) i drutem proszkowym w osłonie gazu ochronnego (FCAW). Zmiennymi parametrami w próbie implant była zawartość wodoru dyfundującego i energia liniowa spawania. Wykazano częściową odporność na zimne pękanie złączy dla badanych zakresów parametrów spawania. Odporność na zimne pękanie zmniejsza się przy wzroście zawartości wodoru dyfundującego w złączu i zwiększeniu szybkości chłodzenia metalu w SWC mierzonej czasem chłodzenia w zakresie temperatury $800 \div 500^{\circ} \mathrm{C}$.

\section{Abstract}

The results of investigations of resistance to cold cracking of welded joints of high strength steel designed to work under pressure P460NL1 have been presented. Welding was carried out with coated electrodes (MMA) and flux cored wire in a shield gas (FCAW). Parameters changed in the implant test was diffusible hydrogen content and weld heat input. It has been shown partial resistance to cold cracking of joints for the studied ranges of welding parameters. Cold cracking resistance decreases with increasing diffusible hydrogen content in the joint and increase the cooling rate in the HAZ metal measured by cooling time in the temperature range $800 \div 500^{\circ} \mathrm{C}$.

\section{Wstęp}

Pękanie zimne występuje w czasie ochładzania złącza spawanego lub po osiągnięciu przez takie złącze temperatury otoczenia ale, przed przekazaniem złącza do eksploatacji, tj. w okresie zwanym procesem technologicznym wytwarzania złącza. Wtedy kończą się rozpoczęte procesy i przemiany. Przykładami takich procesów mogą być: krystalizacja metalu spoiny, przemiany fazowe $\mathrm{w}$ stanie stałym itp. Natomiast przykładami procesów, które się stabilizuja, mogą być: redystrybucja naprężeń spawalniczych, dyfuzja, w tym wodoru, stabilizacja wymiarowa itp. W celu uniknięcia lub zmniejszenia zagrożenia z powodu indukowania pęknięć zimnych wykonano wiele prac badawczych, określono czynniki takiego pękania i sposoby przeciwdziałania temu zjawisku $[1 \div 4]$.

Dr inż. Tomasz Kozak - Politechnika Gdańska.
Pękanie zimne $w$ dalszym ciągu jest problemem, który daje o sobie znać w czasie wykonywania konstrukcji spawanych $[5,6]$.

W artykule przedstawiono warunki, w jakich może dojść do zimnego pękania podczas wykonywania złączy spawanych ze stali o podwyższonej wytrzymałości, przeznaczonej do budowy naczyń ciśnieniowych, dla typowych, często stosowanych metod i warunków spawania. Wzięto pod uwagę spawanie ręczne elektrodami otulonymi (MMA) i spawanie w osłonie gazowej przy zastosowaniu drutu proszkowego (FCAW). W obu metodach jest wprowadzany do złączy wodór powodujący wzrost skłonności do zimnego pękania. llość wodoru jest zależna od warunków spawania oraz od stanu spoiwa przeznaczono do spawania. Drugim zmiennym parametrem charakteryzującym warunki cieplne podczas spawania była energia liniowa spawania, którą zmieniano w zakresie zalecanym dla badanej stali. Skłonność do pękania zimnego określano metodą implant (kołkową). 


\section{Charakterystyka złączy spawanych ze stali P460NL1}

Stal P460NL1 wg PN-EN 10028-3 jest niskostopową, normalizowaną, drobnoziarnistą stalą o podwyższonej wytrzymałości, przeznaczoną do pracy pod ciśnieniem. Najczęściej stosowaną metodą jej spawania jest spawanie ręczne elektrodami otulonymi - ze względu na możliwość łatwiejszego doboru elektrody pod względem zarówno energii liniowej spawania, jak i wytrzymałości złącza. Do łączenia tej stali stosowane jest

Tablica I. Podstawowe wymagane właściwości stali P460NL1 i materiałów dodatkowych do spawania metodami MMAW i FCAW

Table I. The basic required properties of P460NL1 steel and of filler material for FCAW and MMAW

\begin{tabular}{|c|c|c|}
\hline \multicolumn{2}{|c|}{ Materiał rodzimy } & P460NL1 \\
\hline \multicolumn{3}{|c|}{ Właściwości } \\
\hline $\mathrm{R}_{\mathrm{e}} \min$ & $\mathrm{MPa}$ & 460 \\
\hline $\mathrm{R}_{\mathrm{m}} \min$ & $\mathrm{MPa}$ & 570 \\
\hline $\mathrm{K}_{\mathrm{v}} \min$. & $\mathrm{J}$ & 27 \\
\hline Temp. badania. & ${ }^{\circ} \mathrm{C}$ & -50 \\
\hline$A_{5} \min$ & $\%$ & 17 \\
\hline \multicolumn{3}{|c|}{ Materiały dodatkowe spełniające wymagania podstawowe dla złączy } \\
\hline MMA & norma & PN-EN 499 \\
\hline Elektroda & oznaczenie & OK48.08 \\
\hline FCAW & norma & PN-EN 758 \\
\hline Drut proszkowy & oznaczenie & OK15.11 \\
\hline
\end{tabular}

również spawanie w osłonach gazów, pod warunkiem zachowania dużej czystości spoiwa i gazów, oraz spawania automatycznego łukiem krytym pod topnikiem. Energia liniowa łuku powinna być utrzymana na poziomie $1,0 \div 3,0 \mathrm{~kJ} / \mathrm{mm}$. Zalecane jest stosowanie techniki spawania wielościegowego oraz używanie elektrod zasadowych i topników zasadowych lub neutralnych.

$\mathrm{Na}$ tej podstawie dla wybranych metod zaprojektowano wstępne instrukcje technologiczne spawania pWPS złączy doczołowych z badanej stali. Warunki spawania wynikały z charakterystyki materiałów rodzimych, możliwości spełnienia wymagań przez złącza i warunków stosowania materiałów dodatkowych określonych przez ich producenta, zalecanych do spawania określonych konstrukcji. W tablicy I zestawiono wymagane właściwości mechaniczne stali i wybrane materiały dodatkowe do spawania, spełniające podstawowe wymagania. W tablicy II przedstawiono składy chemiczne materiałów złączy spawanych według dokonanej analizy i atestów, a w tablicy III właściwości mechaniczne materiału rodzimego stosowanego w badaniach odporność na pękanie zimne. W tablicy IV podano wyniki pomiarów twardości w poszczególnych obszarach złączy spawanych blach o grubości $25 \mathrm{~mm}$. Pomiarów twardości dokonano twardościomierzem przenośnym EQUOTIP. Złącza spawane poddano badaniom metalograficznym: makroskopowym i mikroskopowym. W tablicy $\mathrm{V}$ przedstawiono fotografie zgładów makroskopowych przekrojów poprzecznych złączy spawanych poszczególnymi metodami oraz fotografie mikrostruktur materiałów

Tablica II. Skład chemiczny materiałów rodzimych i metali spoin złączy spawanych uzyskanych wg atestu lub analizy chemicznej

Table II. Chemical composition of materials and weld metal of welded joints obtained by certificate or chemical composition analysis

\begin{tabular}{|c|c|c|c|c|c|c|c|c|c|c|c|c|c|c|c|}
\hline \multirow{3}{*}{ Stal } & \multirow{3}{*}{$\begin{array}{c}\text { Norma/miejsce } \\
\text { badania }\end{array}$} & \multirow{3}{*}{$\begin{array}{l}\mathrm{Nr} \text { atestu/ } \\
\text { analizy }\end{array}$} & Grubość & \multicolumn{12}{|c|}{ Skład chemiczny } \\
\hline & & & $\mathrm{t}$ & C & $\mathrm{Mn}$ & $\mathrm{Si}$ & $S$ & $\mathrm{P}$ & $\mathrm{Al}$ & $\mathrm{Cu}$ & $\mathrm{Cr}$ & $\mathrm{Ni}$ & V & $\mathrm{Nb}$ & $\mathrm{Ti}$ \\
\hline & & & $\mathrm{mm}$ & \multicolumn{12}{|c|}{$\%$ wag. } \\
\hline P460NL1 & EN10028 & 362638 & 12 & 0,14 & 1,51 & 0,34 & 0,003 & 0,013 & 0,021 & 0,02 & 0,03 & 0,6 & 0,16 & 0 & 0,01 \\
\hline P460NL1 & $\begin{array}{l}\text { Weld-electrode } \\
\text { OK4808 }\end{array}$ & wg analizy & 25 & 0,058 & 1,21 & 0,29 & 0,029 & 0,0027 & 0,013 & 0,027 & 0,012 & 0,66 & 0,038 & 0,016 & 0,038 \\
\hline P460NL1 & Weld- wire OK1511 & wg analizy & 25 & 0,13 & 1,34 & 0,33 & 0,021 & 0,0027 & 0,036 & 0,018 & 0,025 & 0,49 & 0,16 & 0,015 & 0,031 \\
\hline
\end{tabular}

Tablica III. Właściwości mechaniczne materiału rodzimego wg atestu

Table III. Mechanical properties of base material acc. to certificate

\begin{tabular}{|c|c|c|c|c|c|c|c|c|}
\hline \multirow{2}{*}{ Stal } & \multirow{2}{*}{$\begin{array}{c}\text { Norma/miejsce } \\
\text { badania }\end{array}$} & \multirow{2}{*}{$\mathrm{Nr}$ atestu } & $\mathrm{t}$ & $\mathrm{R}_{\mathrm{e}}$ & $\mathrm{R}_{\mathrm{m}}$ & $\mathrm{A}_{5}$ & $\mathrm{~T}$ & $\mathrm{KV}$ śr. \\
\cline { 4 - 10 } & & $\mathrm{mm}$ & $\mathrm{MPa}$ & $\mathrm{MPa}$ & $\%$ & ${ }^{\circ} \mathrm{C}$ & $\mathrm{J}$ \\
\hline P460NL1 & EN10028 & 362638 & 12 & 519 & 615 & 24 & -50 & 58 \\
\hline
\end{tabular}

Tablica IV. Wyniki pomiarów twardości złączy spawanych ze stali P460NL1

Table IV. Results of hardness measurement of welded joints in P460NL1 steel

\begin{tabular}{|c|c|c|c|c|c|c|c|c|c|c|c|c|}
\hline \multirow{3}{*}{ Metoda spawania } & \multicolumn{12}{|c|}{ Twardość HV } \\
\hline & \multicolumn{4}{|c|}{ Metal spoiny } & \multicolumn{4}{|c|}{ SWC } & \multicolumn{4}{|c|}{ Materiał rodzimy } \\
\hline & 1 & 2 & 3 & śr. & 1 & 2 & 3 & śr. & 1 & 2 & 3 & śr. \\
\hline MMA & 197 & 199 & 196 & 197 & 182 & 185 & 180 & 182 & 175 & 183 & 180 & 179 \\
\hline FCAW & 239 & 241 & 234 & 238 & 181 & 189 & 181 & 184 & 171 & 178 & 169 & 173 \\
\hline
\end{tabular}


Tablica V. Makro- i mikrostruktury złączy spawanych ze stali P460NL1. Trawiono 4\% $\mathrm{HNO}_{3}$. Pow. 250x

Table V. Macro- and microstructures of welded joints of P460NL1 steel. Etching: $4 \% \mathrm{HNO}_{3}$ Magn. $250 \mathrm{x}$

\begin{tabular}{|c|c|c|c|c|}
\hline $\begin{array}{c}\text { Zlacze } \\
\text { spawane }\end{array}$ & $\begin{array}{c}\text { Budowa } \\
\text { makroskopowa }\end{array}$ & Materiał rodzimy & Obszar przegrzania & Metal spoiny \\
\hline $\begin{array}{l}\text { Spaw anie } \\
\text { ręczne } \\
\text { MMA }\end{array}$ & & 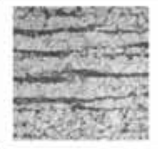 & 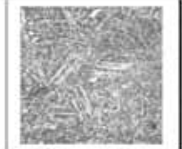 & 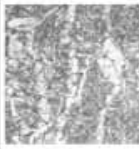 \\
\hline $\begin{array}{c}\text { Spawanie } \\
\text { drutem } \\
\text { proszkowym } \\
\text { FCAW }\end{array}$ & & 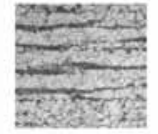 & 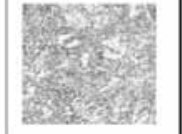 & 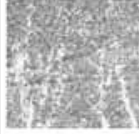 \\
\hline
\end{tabular}

rodzimych, metali spoin i obszaru przegrzania poszczególnych złączy. Ze względu na dość duży materiał badawczy, ograniczono się do przedstawienia mikrostruktur charakterystycznych dla ostatniego ściegu metalu spoiny i obszaru przegrzania przylegającego do ostatniego ściegu w danym złączu. Jak z przedstawionych danych wynika, otrzymane złącza spawane charakteryzują się typową budową makro i mikroskopową i mają typowe właściwości mechaniczne, których wyróżnikiem jest stosunkowo niska twardość w całej objętości.

\section{Wyniki badań eksperymentalnych}

Badania odporności na pękanie zimne przeprowadzono metodą implant wg PN-90/M-69760 z użyciem blach ze stali P460NL1 o grubości $12 \mathrm{~mm}$ [7]. Zastosowano dwie metody spawania z określonymi dla nich zakresami warunków spawania. Zmiennymi parametrami procesu spawania była energia liniowa i zawartość wodoru dyfundującego w złączu. Szczegółowe warunki realizacji prób odporność na pękania metodą implant przedstawiono $\mathrm{w}$ tablicy VI. Próby implant zostały wykonane na stanowisku Implant 02 (rys. 1). Zmiany obciążenia na stanowisku dokonu-

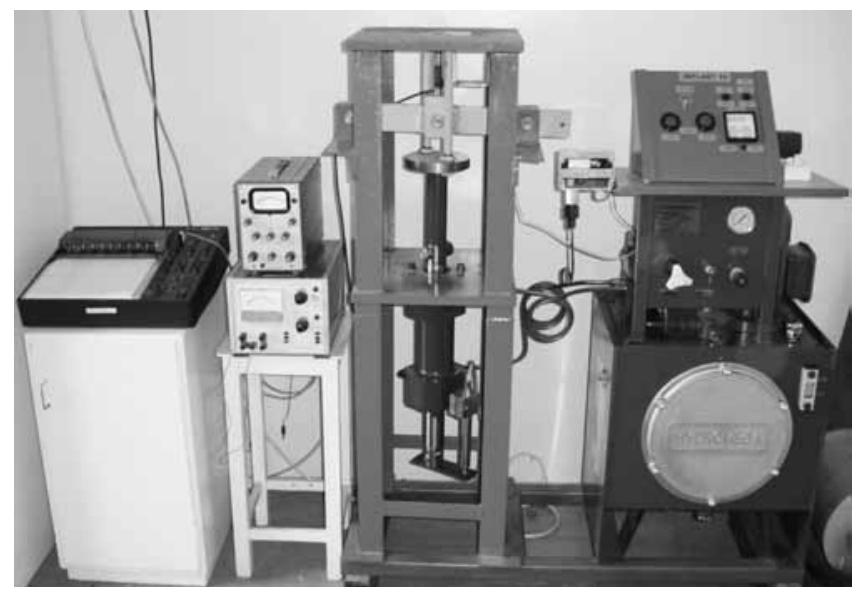

Rys. 1. Stanowisko do pomiarów odporność na pękanie zimne Implant 02

Fig. 1. Position for measuring of susceptibility to cold cracking Implant 02
Tablica VI. Warunki realizacji pomiarów odporności na pękanie zimne Table VI. Conditions for measurement performance of resistance to cold cracking

\begin{tabular}{|c|c|c|}
\hline \multirow{2}{*}{ Metoda spawania } & $\mathrm{H}_{\mathrm{D}}$ & $\mathrm{e}_{\mathrm{L}}$ \\
\cline { 2 - 3 } & $\mathrm{ml} / 100 \mathrm{~g} \mathrm{Fe}$ & $\mathrm{kJ} / \mathrm{mm}$ \\
\hline \multirow{2}{*}{ MMA } & 2,0 & 2,6 \\
\cline { 2 - 3 } & 7,0 & 2,1 \\
\cline { 2 - 3 } & 12,0 & 1,6 \\
\hline \multirow{2}{*}{ FCAW } & 5,0 & 1,0 \\
\cline { 2 - 3 } & 10,0 & 2,4 \\
\hline
\end{tabular}

je się za pomocą nastawnego zaworu redukującego, który utrzymuje założoną wartość ciśnienia oleju w komorze roboczej siłownika. Zależność między siłą obciążającą implant a ciśnieniem panującym w komorze roboczej siłownika jest liniowa. Przed rozpoczęciem badań wykonano kalibrację stanowiska Implant 02 w celu zapewnienia odpowiedniej dokładności pomiarów. Do kalibracji użyto legalizowanej, uniwersalnej maszyny wytrzymałościowej ZDMh30 oraz siłomierza o zakresie pomiarowym $100 \mathrm{kN}$. W wyniku kalibracji uzyskano następującą zależność określającą naprężenia w płaszczyźnie karbu próbki w funkcji ciśnienia w komorze siłownika:

$$
\sigma_{i}=78,204 p-11,357
$$

gdzie: $\sigma_{i}$ - naprężenia w płaszczyźnie karbu próbki, MPa; $\mathrm{p}$ - ciśnienie w komorze siłownika, MPa.

Do realizacji programu badań konieczne było uzyskiwanie zawartości wodoru dyfundującego w złączu na określonym poziomie. Poziomy takie uzyskiwano metodą kontrolowanego nawilżania elektrod. Część informacji o sposobie nawilżania elektrod została zaczerpnięta z literatury [8, 9]. Dla elektrod OK4808 uzyskano następującą zależność określającą relację zawartości wodoru dyfundującego $\mathrm{H}_{\mathrm{D}}[\mathrm{ml} / 100 \mathrm{~g} \mathrm{Fe}]$ od czasu nawilżania $\mathrm{t}_{\mathrm{n}}[\mathrm{h}]$ :

$$
H_{D}=0,6729 t_{n}+2,39
$$

Oznaczenie wodoru dyfundującego wykonano metodą glicerynową zgodnie $z$ warunkami podanymi w [10, 11]. Zawartość wodoru oznaczana na podstawie metody rtęciowej może być określona z następującej zależności [12]:

$$
H_{D} g=0,658 H_{D} r
$$

lub wg [13]:

$$
H_{D} r=1,16 H_{D} g+2,4
$$

gdzie: $H_{D} g$ - zawartość wodoru dyfundującego oznaczonego metodą glicerynową, ml/100 g; $\mathrm{H}_{\mathrm{D}} \mathrm{r}$ - zawartość wodoru dyfundującego oznaczonego metodą rtęciową, $\mathrm{ml} / 100 \mathrm{~g}$, 


\section{Badania odporności na pękanie zimne}

Próby odporności na pękanie zimne wykonano zgodnie z normą PN-90/M-69760 [7]. Liczebność próbek wynosiła 3 dla każdego poziomu naprężenia obciążającego implanty. Pomiary, dla zmiennych poziomów energii liniowej spawania i wodoru dyfundującego przedstawionych powyżej, przeprowadzono dla dwóch metod spawania: ręcznego elektrodą otuloną (MMA) i półautomatycznego w osłonie gazu ochronnego drutem proszkowym (FCAW). Przykładowe wyniki pomiarów przedstawiono na wykresie $\sigma_{i}=f\left(t_{z}\right)$ (rys. 2).

W tablicy VII podano wyniki pomiarów dla założonych warunków spawania, a także wartości wskaźnika odporności na pękanie zimne $\alpha=\sigma_{\mathrm{kr}} / \mathrm{R}_{\mathrm{e}}$, przy czym przyjęto dla stali P460NL1 $R_{e}=519 \mathrm{MPa}$. Przyjmuje się, że jeśli wartość $\alpha<0,6$ stal uważa się za nieodporną na pękanie zimne zimnego, a gdy $0,6<\alpha<1$, stal uważa się za częściowo odporną na pękanie zimne [14].

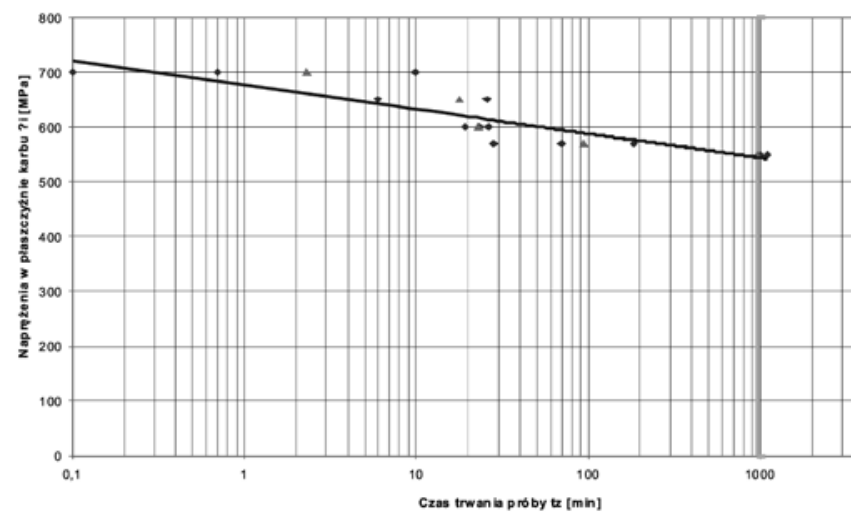

Rys. 2. Wyniki próby implant: stal P460NL1, spawanie metodą MMA, $\mathrm{e}_{\mathrm{L}}=2,6 \mathrm{~kJ} / \mathrm{mm}, \mathrm{H}_{\mathrm{D}}=2 \mathrm{ml} / 100 \mathrm{~g} \mathrm{Fe}, \sigma_{\mathrm{kr}}=550 \mathrm{MPa}$. Naniesiono uśrednione czasy zerwania próbek (trójkąty).

Fig. 2. The results of implant test: Steel P460NL1, MMA welding, $\mathrm{e}_{\mathrm{L}}=2,6 \mathrm{~kJ} / \mathrm{mm}, \mathrm{H}_{\mathrm{D}}=2 \mathrm{ml} / 100 \mathrm{~g} \mathrm{Fe}, \sigma_{\mathrm{kr}}=550 \mathrm{MPa}$. Average times to samples crack (triangles)

Tablica VII. Wyniki pomiarów odporności na pękanie zimne złączy ze stali P460NL1 metodą implant

Table VII. The summary results of implant method measurements of resistance to cold cracking of P460NL1 welded joints

\begin{tabular}{|c|c|c|c|c|c|}
\hline \multirow{2}{*}{ Metoda spawania } & $\mathrm{H}_{\mathrm{d}}$ & $\mathrm{e}_{\mathrm{L}}$ & $\sigma_{\mathrm{kr}}$ & $\mathrm{t}_{8 / 5}$ & $\alpha$ \\
\cline { 2 - 6 } & $\mathrm{ml} / 100 \mathrm{~g} \mathrm{Fe}$ & $\mathrm{KJ} / \mathrm{mm}$ & $\mathrm{MPa}$ & $\mathrm{s}$ & - \\
\hline \multirow{2}{*}{ MMA } & 2,0 & 2,6 & 550 & 11,7 & 1,06 \\
\cline { 2 - 6 } & 7,0 & 2,1 & 480 & 9,4 & 0,93 \\
\cline { 2 - 6 } & 12,0 & 1,6 & 430 & 7,2 & 0,87 \\
\hline \multirow{2}{*}{ FCAW } & 5,0 & 1,0 & 450 & 4,5 & 0,87 \\
\cline { 2 - 6 } & 10,0 & 2,4 & 420 & 10,8 & 0,81 \\
\hline
\end{tabular}

W tablicy VII przedstawiono również czas chłodzenia metalu złączy określony dla warunków wykonywania próby implant. Czas chłodzenia $\mathrm{t}_{8 / 5}$ wyznaczono według zależności określonej w [15]:

$$
t_{8 / 5}=\left(6700-5 \cdot T_{0}\right) \cdot f_{3} \cdot k \cdot e_{L}\left(\frac{1}{500-T_{0}}-\frac{1}{800-T_{0}}\right)
$$

gdzie: $\mathrm{t}_{8 / 5}$ - czas stygnięcia w zakresie temperatury $800 \div 500^{\circ} \mathrm{C}$, $\mathrm{s} ; \mathrm{f}_{3}$ - współczynnik kształtu złącza dla trójosiowego przepływu ciepła, $\mathrm{f}_{3}=1,0 ; \mathrm{k}$ - współczynnik sprawności cieplnej procesu łukowego dla MMA i FCAW; $k=0,85 \mathrm{~T}_{0}$ - temperatura początkowa spawanego elementu, $20^{\circ} \mathrm{C}$; $d-$ grubość płyty pomocniczej $\mathrm{d}=20 \mathrm{~mm}-$ nie wpływa na $\mathrm{t}_{815} ; \mathrm{e}_{\mathrm{L}}$ - energia liniowa spawania, $\mathrm{kJ} / \mathrm{mm}$.

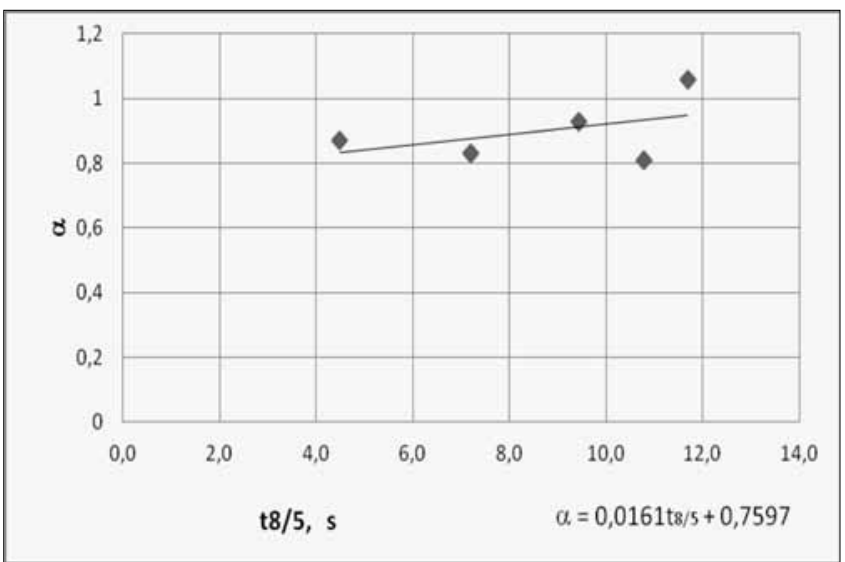

Rys. 3. Wpływ czasu chłodzenia $t_{815}$ na wskaźnik odporności na pękanie zimne $\alpha$ dla złączy spawanych metodą MMA i FCAW stali P460NL1. Nie uwzględniono wpływu zawartości wodoru dyfundującego $\mathrm{H}_{\mathrm{D}}$ w zakresie $2 \div 12 \mathrm{ml} / 100 \mathrm{~g} \mathrm{Fe}$

Fig. 3. Effect of cooling time $t_{85}$ on resistance to cold cracking of weIded joints $\alpha$ for the MMAW and FCAW of P460NL1 steel. It does not include the impact of the diffusible hydrogen content $\mathrm{H}_{\mathrm{D}}$ in range $2 \div 12 \mathrm{ml} / 100 \mathrm{~g} \mathrm{Fe}$

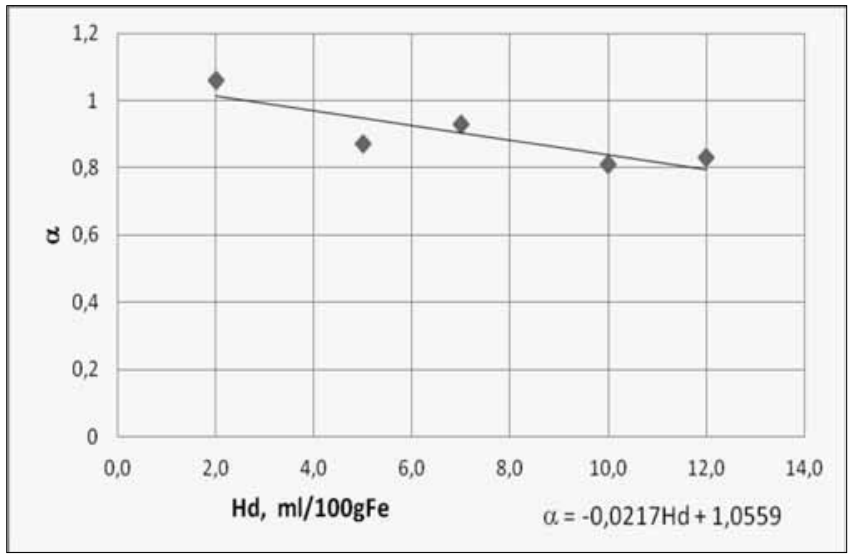

Rys. 4. Wpływ zawartości wodoru dyfundującego $H_{D}$ na wskaźnik odporności na pękanie zimne $\alpha$ dla złączy spawanych metodą MMA i FCAW stali P460NL1. Nie uwzględniono wpływu czasu chłodzenia $\mathrm{t}_{8 / 5} \mathrm{w}$ zakresie $4,5 \div 11,7 \mathrm{~s}$

Fig. 4. Effect of diffusible hydrogen content $H_{D}$ on resistance to cold cracking of welded joints $\alpha$ for the MMAW and FCAW of P460NL1 steel. It does not include the impact of the cooling time $t_{8 / 5}$ in the range $4,5 \div 11,7 \mathrm{~s}$ 


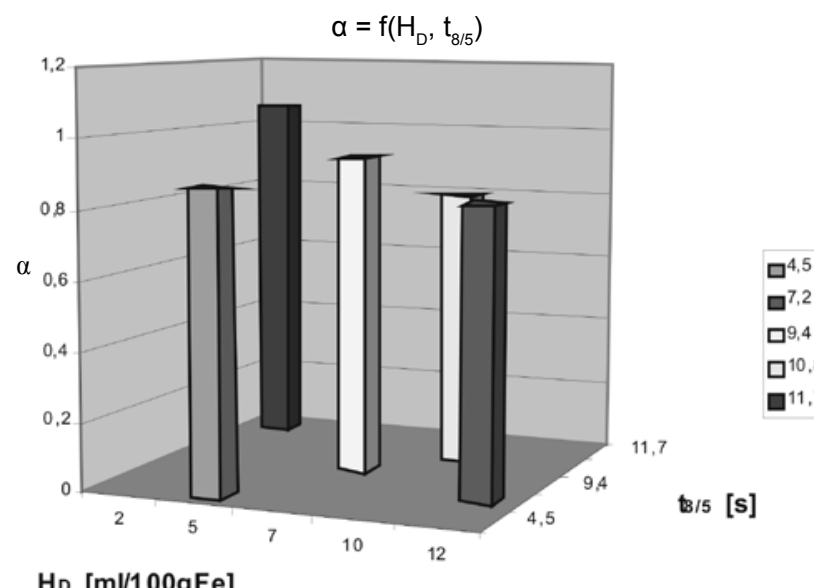

Ho $[\mathrm{ml} / 100 \mathrm{gFe}]$

Rys. 5. Wpływ zawartości wodoru dyfundującego $\mathrm{H}_{\mathrm{D}} \mathrm{i}$ czasu chłodzenia $t_{8 / 5}$ na wskaźnik odporności na pękanie zimne $\alpha$ dla złączy spawanych metodą MMA i FCAW stali P460NL1

Fig. 5. Effect of diffusible hydrogen content HD and the cooling time $t_{815}$ on resistance to cold cracking of welded joints $\alpha$ for the MMAW and FCAW of P460NL1 steel

Energia liniowa była określana z zależności:

$$
e_{L}=0,001 \mathrm{UI} / \mathrm{V}
$$

gdzie: U -napięcie łuku, V; I - natężenie prądu spawania, A; v - prędkość spawania, $\mathrm{mm} / \mathrm{s}$.

Parametry badań odporności na pękanie zimne zmieniały się w znacznym zakresie $1,6 \div 2,6 \mathrm{~kJ} / \mathrm{mm}$. Dla procesu napawania implantów odpowiadało to czasom chłodzenia $\mathrm{t}_{85}=4,5 \div 11,7 \mathrm{~s}$. Drugi parametr, zawartość wodoru dyfundującego, zmieniano w zakresie
$\mathrm{H}_{\mathrm{D}}=2 \div 12 \mathrm{ml} / 100 \mathrm{~g} \mathrm{Fe} . \mathrm{Z}$ wyników badań wynika, że wraz ze wzrostem zawartości wodoru dyfundującego i zmniejszeniem energii liniowej spawania, a zatem skróceniem czasu chłodzenia w zakresie $800 \div 500^{\circ} \mathrm{C}$, następuje spadek odporności na zimne pękanie wyrażany spadkiem wartości naprężenia krytycznego lub wskaźnika $\alpha$. Zależności te przedstawiono na wykresach, pokazujących wartość wskaźnika odporności na pękanie zimne $\alpha$ funkcji czasu chłodzenia w SWC i zawartości wodoru dyfundującego $\mathrm{H}_{\mathrm{D}}$ (rys. 3 i 4 ) można wnioskować, że czas chłodzenia $t_{855}$ wpływa bardzo nieznacznie na wartość $\alpha$, podczas gdy zauważa się znaczny wpływ zawartości wodoru dyfundującego na jego wartość. Można również zauważyć, że wpływ tych parametrów na odporność na pękanie zimne jest prawidłowy. Ponadto, z wykresów tych wynika, że w czasie spawania stal P460NL1 wykazuje częściową odporność na zimne pękanie, gdyż praktycznie, niezależnie od wartości $\mathrm{t}_{8 / 5} \mathrm{i}_{\mathrm{D}}$, wskaźnik $\alpha$ przyjmuje wartości pomiędzy 0,6 i 1,0. Jedynie dla małej szybkości chłodzenia $\left(t_{8 / 5}=11,7 \mathrm{~s}\right)$ i małej zawartości wodoru dyfundującego, tj. $\mathrm{H}_{\mathrm{D}}=2 \mathrm{ml} / 100 \mathrm{~g} \mathrm{Fe}$, wskaźnik $\alpha>1$. Bardzo wyraźnie można te zależności odczytać $z$ wykresu $\alpha=f\left(H_{D}, t_{815}\right)$, przedstawionego na rysunku 5 . Wartość wskaźnika odporności na pękanie zimne $\alpha$ maleje ze wzrostem zawartości wodoru dyfundujące-

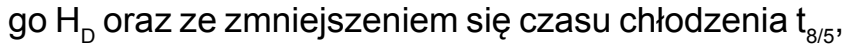
a zatem zwiększeniem szybkości chłodzenia w SWC złącza. Warto również zauważyć, że przedstawione na rysunkach $3 \div 5$ wyniki, pomimo tego, że uzyskane przy spawaniu dwiema metodami, ukazują spójność w przedstawieniu wpływu podstawowych parametrów procesu na odporność na pękanie zimne.

\section{Wnioski}

Z badań odporności na zimne pękanie złączy spawanych elektrodami otulonymi i drutem proszkowym stali P460NL1 można wyciągnąć następujące wnioski:

- Badania odporności na pękanie zimne przeprowadzono metodą implant dla standardowych, zalecanych warunków spawania i dwóch zmiennych parametrów, tj. energii liniowej $w$ zakresie $1,6 \div 2,6 \mathrm{~kJ} / \mathrm{mm}$ i zawartości wodoru dyfundującego w zakresie $H_{D}=2 \div 12 \mathrm{ml} / 100 \mathrm{~g} \mathrm{Fe}$.

- Założone poziomy wodoru dyfundującego w złączach spawanych uzyskiwano po kontrolowanym nawilżaniu elektrod otulonych.

- Warunki spawania w próbie implant powodowały zmianę czasu chłodzenia metalu w SWC w zakresie temperatury $\mathrm{t}_{8 / 5}=4,5 \div 11,7 \mathrm{~s}$.
- Naprężenie krytyczne $\sigma_{k r}$ i wskaźnik odporności na pękanie zimne $\alpha=\sigma_{\mathrm{kr}} / \mathrm{R}_{\mathrm{e}}$ wyznaczone w próbie implant dla badanej stali są zależne od zawartości wodoru dyfundującego $\mathrm{H}_{\mathrm{D}} \mathrm{i}$ czasu chłodzenia $\mathrm{t}_{815}$.

- Zależność wskaźnika odporności $\alpha$ jako funkcji $\mathrm{H}_{\mathrm{D}} \mathrm{i}_{8 / 5}$ przedstawiono tablicy VII i na rysunku 5. Ze wzrostem zawartości wodoru dyfundującego $H_{D}$ i skróceniem czasu chłodzenia $t_{8 / 5}$, a tym samym zwiększeniem szybkości chłodzenia metalu w SWC, następuje spadek odporności stali P460NL1 na zimne pękanie w czasie spawania.

- Stal P460NL1 w czasie spawania elektrodami otulonymi i drutem proszkowym w osłonie gazowej, dla standardowych warunków, wykazuje częściową odporność na pękanie zimne (wskaźnik odporności na pękanie $0,6<\alpha<1$ ). 


\title{
Literatura
}

[1] Butnicki S.: Spawalność i kruchość stali. WNT, Warszawa 1991.

[2] Tasak E.: Spawalność stali. FOTOBIT, Kraków 2002.

[3] Tasak E.: Metalurgia spawania. JAK, Kraków 2008.

[4] Ranatowski E.: Elementy fizyki spajania metali. Wyd. Akademii Techniczno-Rolniczej. Bydgoszcz 1999.

[5] Łomozik M., Dębski E.: Ustalenie przyczyn i rodzaju pęknięć w złączach spawanych kadłuba statku. Biuletyn Instytutu Spawalnictwa. Gliwice, 3/2000.

[6] Kozak T.: Pękanie opóźnione w aspekcie mechaniki pękania. Biuletyn Instytutu Spawalnictwa 6/2005.

[7] Badania skłonności do tworzenia pęknięć zimnych w złączach spawanych łukowo. PN-90/M-69760.

[8] Sitko J.: Wpływ wilgoci w otulinie i parametrów suszenia elektrod na zawartość wodoru dyfundującego w stopiwie elektrod zasadowych. Przegląd Spawalnictwa 3/1987.

[9] Opatrny-Myśliwiec D.: Pomiar zawartości wodoru dyfundującego w złączu spawanym łukowo-ręcznie, w zależności od gatunku elektrody i stanu powierzchni. Politechnika Gdańska. Gdańsk. 1980, materiały niepublikowane.
[10] Oznaczanie całkowitej ilości wodoru w stopiwie stalowych elektrod $\mathrm{z}$ otuliną kwaśną, rutylową lub zasadową. BN-64/4130.

[11] Przepisy klasyfikacji i budowy statków morskich. Część IX Materiały i spawanie. PRS. Gdańsk 2002.

[12] Mazur M., Grela P.: Badania porównawcze wodoru dyfundującego ze stopiwa metodami glicerynową i rtęciową. Biuletyn Instytutu Spawalnictwa, 1/2002r.

[13] Changying T. i in.: The investigation of Implant Cold Cracking Test. IIW-Doc. IX-1729-94.

[14] Mikuła J.: Zastosowanie metod obliczeniowych w ocenie spawalności stali - wskaźniki spawalności. Przegląd Spawalnictwa, 8/1993.

[15] Spawanie. Wytyczne spawania metali. Część 2. Wytyczne spawania stali ferrytycznych. PN-EN 1011-2:2001.

Praca była finansowana ze środków budżetowych na naukę w latach 2005-2008.

\section{\$\& 4METAL.PL}

\section{Ponad 2000 podwykonawców z całego świata}

\author{
[katalog firm] PONAD 2000 FIRMZ Z CAEEGO SWATA \\ E mww.4metal.pl \\ [giełda pracy] I OgRACODARANCOWZ BraNZY \\ $\square$ wrw.4metal.de \\ munv.4metal.cz

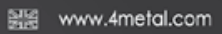 \\ Emww.4metal.nl \\ [giełda maszyn] RONAD 2300 AKTUALNYCH OGLOSZEN \\ Emw.4metal.at \\ II nuw.4metal.be \\ [Wydarzenia] $]_{\text {ZE SWIATA }}^{\text {LSTAGOW IMPREZ BRANZOWYCH }}$ \\ E mmw.4metal.ru \\ [aktualności] TECHNOLOGIE, WYWMADY, SPRAWOZDANIA. \\ (1) unw.4metal.ch \\ II mww.4metalit \\ [media] INFORMAGJE O CZASOPISMACH \\ II wnw.4metal.ro \\ [video] RELAGE, WrWIAdY, \\ $\nexists$ muw.4metal.hu \\ 吾 nnw.4metal.us
}

